\title{
Standard Environmental Condition
}

National Cancer Institute

\section{Source}

National Cancer Institute. Standard Environmental Condition. NCI Thesaurus. Code C134026.

A single set of environmental conditions. 